\title{
Influence of Blanching on the Production of Pectinases from Banana Peels by Aspergillus niger
}

\author{
Ogunlade Ayodele Oluwayemisi ${ }^{1, *}$, Aladejana Oluwatoyin Modupe ${ }^{2}$ \\ ${ }^{1}$ Department of Food Technology, School of Science and Computer Studies, The Federal Polytechnic Ado Ekiti, Ado Ekiti, Ekiti State, \\ Nigeria \\ ${ }^{2}$ Department of Biological Sciences, Microbiology Unit, Faculty of Science, Kings University, Ode Omu, Osun State, Nigeria
}

\section{Email address:}

ayoyemi19@gmail.com (O.A. Oluwayemisi)

*Corresponding author

\section{To cite this article:}

Ogunlade Ayodele Oluwayemisi, Aladejana Oluwatoyin Modupe. Influence of Blanching on the Production of Pectinases from Banana Peels by Aspergillus niger. International Journal of Microbiology and Biotechnology. Vol. 4, No. 1, 2019, pp. 8-11.

doi: $10.11648 /$ j.ijmb.20190401.12

Received: January 22, 2019; Accepted: February 28, 2019; Published: March 26, 2019

\begin{abstract}
Pectinases are enzymes that break down pectin, a polysaccharide found in plant cell walls into simpler molecules. They are commonly referred to as pectic enzymes. Influence of blanching was determined on the production of pectinases from banana peels by Aspergillus niger. Banana peels were subjected to blanching with cold $5 \% \mathrm{NaCl}$. Aspergillus niger isolated from decaying banana peels using potato dextrose agar (PDA) were screened for the production of pectinases by examining the isolates with the largest zone of clearance. Solid state fermentation (SSF) and submerged fermentation (SMF) were carried out with the banana peels as the substrate (carbon source) using the Aspergillus niger with the largest zone of clearance. The result revealed that SSF has the highest yield of polygalacturonase and pectin lyase production and both were produced on day 3 of the fermentation having values of $7.5544 \mathrm{U} / \mathrm{mL}$ and $22.3214 \mathrm{U} / \mathrm{mL}$ respectively. It was observed that yield of production was generally higher in blanched banana peels when compared with unblanched banana peels. Subjection of banana peels to blanching with cold $\mathrm{NaCl}$ solution in solid state fermentation gave higher levels of pectinases activity when compared with banana peels that were not treated at all. Therefore blanching of banana peels for pectinases production is of great importance.
\end{abstract}

Keywords: Pectinases, Blanching, Banana Peels

\section{Introduction}

Pectinase is an enzyme that breaks down pectin. Pectin is one of the compounds found in plant cell walls; it is in the plate, (middle lamella) that is the first part of the wall to be formed during cytokinesis, following cell division. Pectinases therefore help to break down the cell walls. This increases the volume of juice obtained (increases the yield), lowers the viscosity of the juice (makes it more runny), reduces the cloudiness of the juice, cause by suspended pieces of cell wall [1].

Pectinase production occupies about $10 \%$ of the overall manufacturing of enzyme preparations. These enzymes are widely used in the food industry for juice and wine production [2]. In nature, microorganisms have been endowed with vast potentials. They produce an array of enzymes, which have been exploited commercially over the years. Pectinases are of great significance with tremendous potential to offer to industry [3]. They are one of the upcoming enzymes of the commercial sector, especially the juice and food industry [4] and in the paper and pulp industry [5]. Production of pectinases has been done from cheaper sources such as agricultural waste; thou a very low yield have been derived. Hence there is a need to improve the yield of the enzyme.

Solid state fermentation (SSF) and submerged fermentation $(\mathrm{SmF})$ are important fermentation methods employed for the production of microbial enzymes [6-7]. The advantages of SSF over the SmF process include higher yield of products [8], generation of less effluent and requirement of 
simpler equipment [9]. This research therefore sought to assess the effect of blanching on the production of pectinases from banana peels by Aspergillus niger.

\section{Materials and Methods}

\subsection{Sample Collection}

Banana peels were collected from Ibadan metropolis and were transported to the University of Ibadan postgraduate laboratory for analysis.

\subsection{Isolation and Characterization of the Isolates}

Decaying banana peels were collected from fruit sellers within the University of Ibadan and then transported to the laboratory for analysis. Ten grams of the fungi infected region of the banana peels were weighed into $90 \mathrm{~mL}$ of sterile distilled water and was shaken properly to obtain the stock solution. Dilutions of $10^{-4}$ were made and pour plating of $10^{-2}$ and $10^{-3}$ was done using sterile Potato Dextrose Agar (PDA) which was sterilized by autoclaving at $121^{\circ} \mathrm{C}$ for $15 \mathrm{mins}$. Streptomycin was added to the PDA to prevent bacterial contamination. The above dilutions were then plated in duplicates. The inoculated plates were incubated at $25 \pm 2{ }^{\circ} \mathrm{C}$ (room temperature) for 5-7days. Pure cultures were obtained by repeated sub-culturing on PDA plates and maintained on PDA slants. The isolates were examined and identified in the Department of Microbiology, University of Ibadan based on cultural and morphological characteristics of the organism. The microscopic structures of the isolates were studied using microscope. Compendium of soil fungi was also consulted.

\subsubsection{Identification of Isolates}

Cultural and Morphological identification of the isolates were carried out by point inoculation of the organism on Potato Dextrose Agar plate containing streptomycin which inhibits the growth of any bacteria. The plates were then incubated for 5-7days after which colony diameter, color, conidia, reverse of the plates, exudates and colony texture were observed and recorded. Microscopic characteristics for the identification was carried out for colour, conidial heads, stipes, length, seriation, , colony texture and shape by mounting the small quantity of the mould carefully in a drop of lacto-phenol blue on a microscope slide and covering it with cover slip and view under the microscope.

\subsubsection{Preparation of Inoculum}

The inoculum for fungi was prepared using 6-day old culture on PDA One disc of respective fungal hyphae was introduced into $5 \mathrm{ml}$ of sterile distilled water, the suspension was mixed using shaker for $10 \mathrm{mins}$ for proper dispersion of the spores.

\subsubsection{Inoculation and Screening}

The isolates were screened for pectinases producing ability by inoculating them in a sterile medium containing $1 \%$ citrus pectin, $\quad 0.14 \% \quad\left(\mathrm{NH}_{4}\right)_{2} \mathrm{SO}_{4}, \quad 0.20 \% \quad \mathrm{~K}_{2} \mathrm{HPO}_{4}, \quad 0.02 \%$ $\mathrm{MgSO}_{4} .7 \mathrm{H}_{2} \mathrm{O}, 0.1 \%$ Nutrient solution $\left(5 \mathrm{Mg} / \mathrm{L} \mathrm{FeSO} 4.7 \mathrm{H}_{2} \mathrm{O}\right.$,
1.6Mg/L $\left.\mathrm{MnSO}_{4}, 1.4 \mathrm{mg} / \mathrm{L} \mathrm{ZnSO}_{4} .7 \mathrm{H}_{2} \mathrm{O}, 2.0 \mathrm{mg} / \mathrm{L} \mathrm{CoCl} 2\right), 3 \%$ agar $\mathrm{pH} 5.0$ [10].

The medium was sterilized and distributed aseptically on petri dishes. The plates were then inoculated with the organism and incubated for 3-5 days. After incubation plates were stained with iodine solution. Clear zones were formed around the pectinase producing isolates.

\subsection{Quantitative Estimation of Pectinase Activity of Screened Isolates}

Quantitative estimation of pectinases activity was done on submerged and solid state fermentation.

\subsubsection{Submerged Fermentation}

The liquid medium containing $0.6 \%\left(\mathrm{NH}_{4}\right)_{2} \mathrm{SO}_{4}, 0.6 \%$ $\mathrm{K}_{2} \mathrm{HPO}_{4}, 0.6 \% \mathrm{KH}_{2} \mathrm{PO}_{4}$, and $\mathrm{MgSO}_{4} .7 \mathrm{H}_{2} \mathrm{O} 0.01 \%$ with $1 \%$ pure pectin and $1 \%$ dry banana peels as the sole carbon sources and these were added separately to the basal medium. The ${ }_{\mathrm{p}} \mathrm{H}$ value was adjusted to 5.5 before sterilization at $121^{\circ} \mathrm{C}$ for $15 \mathrm{mins}$. The pectinase isolates identified was used for inoculation using a flamed and cooled cork borer two disc of fungal hyphae from leading edge of actively growing colonies was cut on petri plates with a flamed and cooled needle disc were then transferred to the fermentation medium in sterile flasks and the Erlenmeyer flasks were then plugged properly and incubated for 12 days at room temperature $\left(25+2^{\circ} \mathrm{C}\right)$. Aliquots were withdrawn every day $3,6,9$, and 12 using Whatman No 1 filter paper for carrying out enzyme assays.

\subsubsection{Preparation of Substrate for Solid State Fermentation}

Fresh banana peels were dried, ground and sieve to obtain smaller substrate particle which provides larger surface area for microbial attack [11].

\subsubsection{Production of Pectinolytic Enzyme by Solid State Fermentation}

Solid state fermentation was carried out using a medium containing 15 grams of ground dried banana peels and $10 \mathrm{~mL}$ of the mineral salt solution of $0.6 \%\left(\mathrm{NH}_{4}\right){ }_{2} \mathrm{SO}_{4}, 0.6 \%$ $\mathrm{K}_{2} \mathrm{HPO}_{4}, 0.6 \% \quad \mathrm{KH}_{2} \mathrm{PO}_{4}$, and $\mathrm{MgSO}_{4} .7 \mathrm{H}_{2} \mathrm{O} \quad 0.01 \%$. The medium was sterilized at $121^{\circ} \mathrm{C}$ for 40 mins (Martins et al., 2004). One disc of respective fungal hyphae was introduced into $5 \mathrm{~mL}$ of sterile distilled water, the suspension was shaken using shaker for 10 mins for proper dispersion of the spores. From this suspension, $1 \mathrm{~mL}$ was withdrawn and inoculated into each flask. The flasks were then incubated at room temperature $\left(25 \pm 2^{\circ} \mathrm{C}\right)$ for 12 days. $50 \mathrm{ml}$ of sterile distilled water was added on day $3,6,9$, and 12 and then filtered. The obtained filtrates were used for conducting enzyme assays.

\subsection{Effect of Blanching on Pectinases Production}

Banana peels were dipped inside $5 \% \mathrm{NaCl}$ and removed at different time intervals of $5 \mathrm{mins}, 10 \mathrm{mins}, 15 \mathrm{mins}$, and $20 \mathrm{mins}$. $15 \mathrm{grams}$ of the substrate was weighed and $10 \mathrm{~mL}$ of 
mineral solution containing $0.6 \%\left(\mathrm{NH}_{4}\right)_{2} \mathrm{SO}_{4}, 0.6 \% \mathrm{~K}_{2} \mathrm{HPO}_{4}$, $0.6 \% \mathrm{KH}_{2} \mathrm{PO}_{4}$, and $\mathrm{MgSO}_{4} .7 \mathrm{H}_{2} \mathrm{O} 0.01 \%$. The medium was sterilized at $121{ }^{\circ} \mathrm{C}$ for $40 \mathrm{mins}$ [10]. One disc of respective fungal hyphae was introduced into $5 \mathrm{~mL}$ of sterile distilled water. The suspension was shaken using shaker for $10 \mathrm{mins}$ for proper dispersion of the spores. From this suspension, $1 \mathrm{~mL}$ was withdrawn and inoculated into each flask. Part of this treated peels were also dried and allowed to be subjected to the fermentation also. The flasks were then incubated at room temperature $\left(25+2^{\circ} \mathrm{C}\right)$ for 12 days. $50 \mathrm{ml}$ of sterile distilled water was added on day 3, 6, 9, and 12 and then filtered. Filtrate was then used as crude enzyme for assay.

\subsubsection{Polygalacturonase Assay}

Polygalacturonase (PG) activity was determined by measuring the release of reducing groups from citrus pectin using the 3, 5 dinitrosalicylic acid (DNS) reagent [12]. The reaction mixture containing $2 \mathrm{~mL}$ of $1 \%$ citrus pectin in $0.2 \mathrm{M}$ phosphate citrate buffer $\mathrm{P}^{\mathrm{H}}(5.5)$ and $0.5 \mathrm{~mL}$ of crude enzyme solution was incubated at $40^{\circ} \mathrm{C}$ for $10 \mathrm{mins}$ [13], a modified method. After this $3 \mathrm{~mL}$ of DNS reagent was added and boiled in water bath for $15 \mathrm{mins}$. After cooling, colour absorbance was read at $540 \mathrm{~nm}$ using a spectrophotometer.

\subsubsection{Pectin Lyase Assay}

Pectin lyase activity was determined by measuring the increase in absorbance at $235 \mathrm{~nm}$ of substrate solution $(0.8 \mathrm{~mL}$ of $1 \%$ citrus pectin in $0.2 \mathrm{M}$ tris $\mathrm{Hcl}$ buffer $\mathrm{PH} 8.5$ hydrolysed by $0.2 \mathrm{~mL}$ enzyme solution at $40^{\circ} \mathrm{C}[10]$.

\section{Results}

\subsection{Production of Polygalacturonase and Pectin-lyase by Aspergillus Niger}

Figure 1 shows the production of polygalacturonase enzymes by Aspergillus niger in both solid state fermentation (SSF) and submerged fermentation (SMF). The fermentation was carried out for 12days and assay of the aliquots was conducted on day $3,6,9,12$. For (SSF) the highest yield of polygalacturonase was produced on day 3 of the fermentation and the value ranged from $4.9676-7.5544 \mathrm{U} / \mathrm{mL}$. However in SMF the polygalacturonase produced ranged from 4.6265$5.3118 \mathrm{U} / \mathrm{mL}$ and the highest yield of production was observed on day 9 with $5.3118 \mathrm{U} / \mathrm{mL}$. Generally from this study SSF was higher than SMF.

Figure 2 shows the production of pectin lyase enzymes by Aspergillus niger in both solid state fermentation (SSF) and submerged fermentation (SMF). For SSF the highest yield of production was observed on day 3 with $22.3214 \mathrm{U} / \mathrm{ml}$, while the lowest was seen on day 12 with $19.0178 \mathrm{U} / \mathrm{ml}$. For SMF the highest yield of pectin lyase production was observed on day 12 having $18.8393 \mathrm{U} / \mathrm{ml}$.

Figure 3 shows the production of the enzyme by Aspergillus niger in solid state fermentation (SSF) and it was observed that yield of production was generally higher in blanched banana peels than unblanched banana peels.

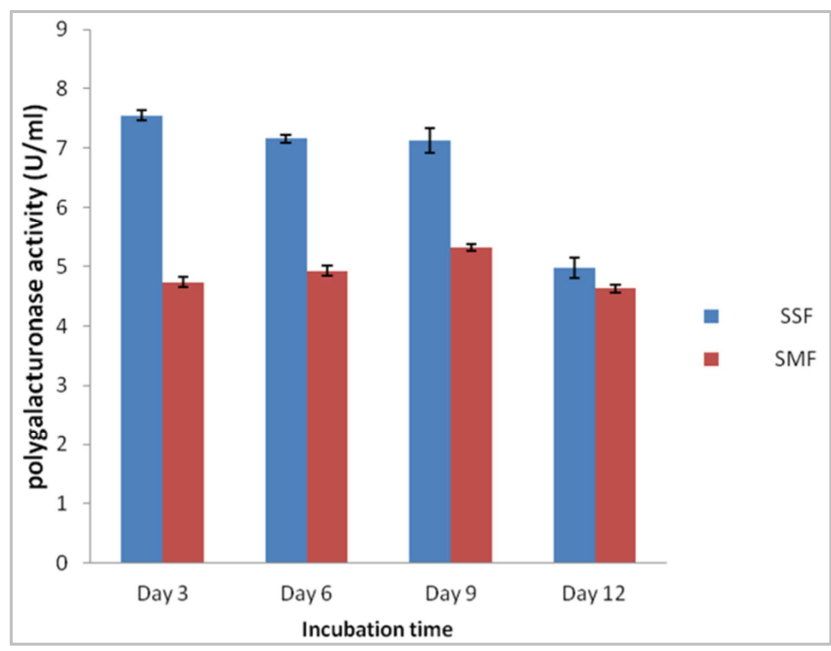

Figure 1. Production of polygalacturonase by Aspergillus niger using blanched banana peels in solid state fermentation (SSF) and Submerged fermentation (SMF).

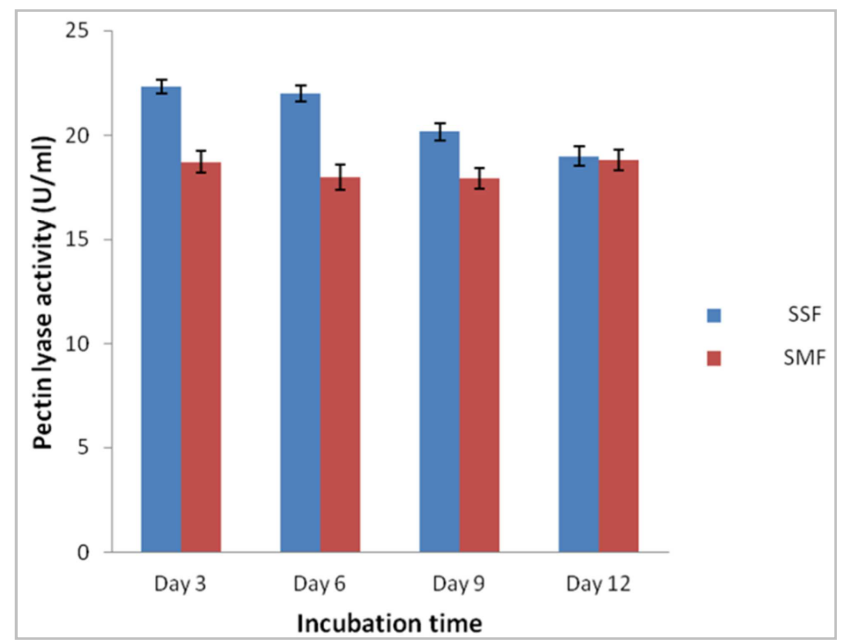

Figure 2. Production of Pectin lyase by Aspergillus niger using blanched banana peels in solid state fermentation (SSF) and Submerged fermentation $(S M F)$.

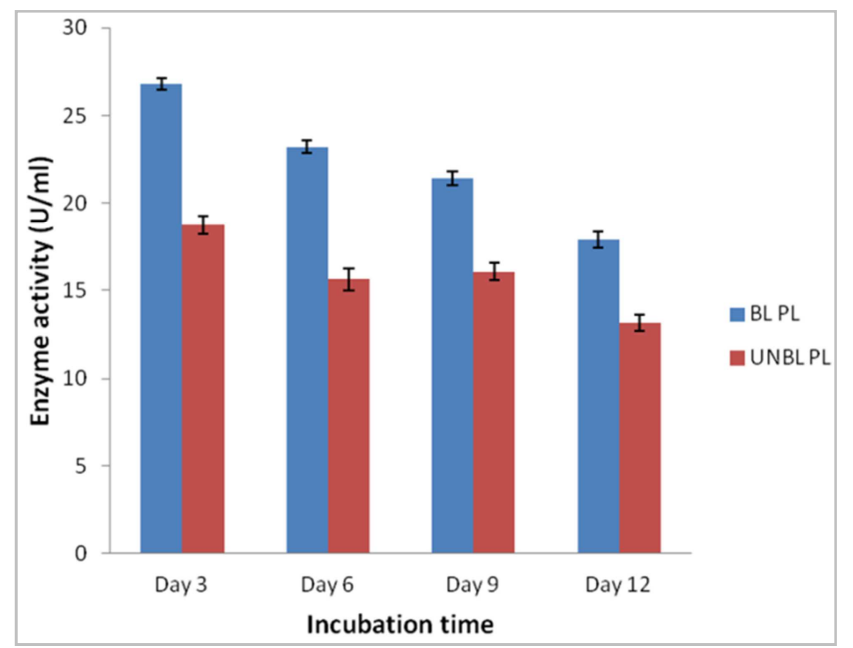

Figure 3. production of enzymes by Aspergillus niger using blanched and unblanched peels in solid state fermentation.

Key BL PL- Blanched peel

UNBL PL- Unblanched peel 


\section{Discussion}

Pectinase production from Solid state fermentation (SSF) culture of Aspergillus niger was significantly higher than that obtained by submerged fermentation $(\mathrm{SmF})$. The higher level of pectinase activity by SSF is observed in polygalacturonase and pectin lyase. Several workers proposed the use of SSF for pectinase production, using different solid agricultural and agro-industrial residues as substrates such as wheat bran, banana peels and soy bean [14-16]. The present result clearly supports the use of SSF over SmF for pectinases production by filamentous fungi.

Banana peels blanched with Nacl gave higher yield of pectinases production compared with peels that were not treated at all. Many researchers have studied the effect of agrowaste pre-treatment by alkali or steam [17-18]. The result obtained in this research is similar to the findings of $[10 ; 19]$ who also recorded higher polygalacturonase and pectin lyazse production by $A$. niger. Increase in enzyme production with additional carbon source have been demonstrated by both SMF and SSF [20]. Fungi thrive on waste plant matter and are capable of utilizing such waste materials as carbon sources in their culture media [21].

\section{Conclusion}

The use of banana peels for the production of pectinases serves as low cost substrate in which a strain of fungi Aspergillus niger was used. Subjection of banana peels to blanching with cold Nacl solution in solid state fermentation gave higher levels of pectinase activity when compared with peels that were not treated at all. The use of banana peels for pectinase production will not only reduce the production costs of the enzyme but also help decrease pollution-load due to the agro-industrial waste.

\section{References}

[1] Mehraj, P. K., Anuradha, P and Subbarao, D. (2013) Application of pectinases in industrial sector. International Journal of Pure and Applied Sciences and Technology. 16(1)8995.

[2] Semenova, M, Sinitsyna O, Morozova, V (2006). Use of a preparation from fungal pectin lyase in the food Industry. Applied Biochemical Microbiology, 42: 598-602.

[3] Dayanand, A and Patil, S. R (2003) In: Detection of potential fungal isolates for the production ofpectinase from deseeded dried sunflower head.

[4] Kashyap, D. R, Vohra, P. K, Chopra S, and Tewari, R (2001). Applications of pectinases in commercial sector: a review. Bioresources Technology; 77:215-27.

[5] Beg, Q. K., Kapoor, M., Tiwari, R. P, Hoondal, G. S (2001). Bleach-boosting of eucalyptus kraft pulp using combination of xylanase and pectinase from Streptomyces $s p$. QG-11-3. Resource Bulletin. Panjab University; 57:71-8.

[6] Kavitha, R and Umesh-Kumar, S (2001). Genetic improvement of
Aspergillus carbonarius for pectinase overproduction during solid state growth, Biotechnology and Bioengineering., 67: 121-125.

[7] Martins, E. S, Silva, R and Gomes, E (2000). Solid state production of thermostable pectinases from thermophilic Thermoascus aurantiacus. Process Biochemistry, 37: 949-954.

[8] Pandey, A (1994). Solid-State Fermentation: An overview. In: Solid State Fermentation, A. Pandey (Ed.), Wiley Eastern Ltd. New Delhi, India, pp. 3-10.

[9] Bennett, J. W (1998). Mycotechnology: The role of fungi in biotechnology. Journal of Biotechnology., 66: 101-107.

[10] Martin, N., De Souza, S. R., Da Silva, R and Gomes, E (2004). Pectinase production by fungal strains in solid-state fermentation using agroindustrial bioproduct, Brazillian Archeology Biology and Technology., 47: 813-819.

[11] Pandey, A., Selvakumar, P., Soccoi, C. R and Nigam, P (2002). Solid State Fermentation for the Production of Industrial enzymes.http://tejas.serc.iisc.ernet.in/ currsci/july10/articles 23 .

[12] Miller, G. L (1959). Use of Dinitrosalicylic acid reagent for determination of reducing sugars. Analytical Chemistry. 31:426-429.

[13] Rangarajan, V., Rajasekaran, M., Ravichandran, R., Sriganesh, $\mathrm{K}$ and Vaitheeswaran, V (2010). Pectinase production from orange peel extract and dried orange peel solid as substrate using Aspergillus niger, International Journal of Biotechnology and Biochemistry; 6:445-453.

[14] Nazneen, A. M., Alam, M., Azim, U., Feroza B., Tipu, S and Abul, K. A (2011). Production of Pectinase by Aspergillus niger Cultured in Solid State Media. International Journal of Biosciences (IJB), 1(1): 33-42.

[15] Castilho, L. R., Alves, T. L. M and Medronho, R. A (2000). Production and extraction of pectinases obtained by solid-state fermentation of agroindustrial residues with Aspergillus niger. Bioresources Technology. 71: 45-50.

[16] Singh, S. A, Plattner, H and Diekmann, H (1999). Exopolygalacturonate lyase from a thermophilic Bacillus $s p$. Enzymology of Microbial Technolology, 25: 420-425.

[17] Okeke, B. C, Obi, S. K. C (1994). Lignocellulose and sugar compositions of some agro waste materials. Bioresources Technology. 50: 222-227.

[18] Ekhlund, R., Galbe, M and Zachi, G (1990). Optimization of temperature and enzyme concentration in the enzymatic saccharification of steam pre-treated willow. Enzyme Microbiology and Technology 12: 225-228.

[19] Ramanujam, P. K ., Saritha, N and Subramanian, P (2008). Production of pectin lyase by solid state fermentation of sugarcane bargasse using Aspergillus niger. Advanced Biotechnology. Pp 30-33.

[20] Mrudula, S and Anitharaj, R (2011). Pectinase production in solid state fermentation by Aspergillus niger using Orange peel as substrate. Global Journal of Biotechnology and Biochemistry, 6(2): 64-71.

[21] Nwodo-Chinedu, S., Okochi, V. I, Omidiji, O., Omowaye, O. O., Adeniji, B. R., Olukoju, D and Chidozie, F (2007b). Potentials of cellulosic wastes in media formulation. African Journal of Biotechnology, 6(3): 243-246. 